\title{
First report of the invasive eel pest Pseudodactylogyrus bini in North America and in wild American eels
}

\author{
Craig J. Hayward ${ }^{1, *}$, Makoto Iwashita ${ }^{1}$, John S. Crane ${ }^{2}$, Kazuo Ogawa ${ }^{1}$ \\ ${ }^{1}$ Department of Aquatic Bioscience, Graduate School of Agriculture, University of Tokyo, Yayoi 1-1-1, Bunkyo-ku, \\ Tokyo 113-8657, Japan \\ ${ }^{2}$ South Carolina Department of Natural Resources, 1921 Van Boklen Road, Eastover, South Carolina 29044, USA
}

\begin{abstract}
We detected 2 species of monogenean gill worms, Pseudodactylogyrus bini (Kikuchi, 1929) Gusev, 1965 and P. anguillae (Yin \& Sproston, 1948) Gusev, 1965 (Monopisthocotylea: Pseudodactylogyridae), on American eel Anguilla rostrata in 2 rivers in South Carolina, USA. One of these, $P$. anguillae, was reported 5 yr ago from Nova Scotia; as well as in South Carolina, we also discovered it in 2 localities in Chesapeake Bay. Differences in the morphologies of specimens of either species of worm from North America and northeastern Asia were negligible. Similarly, the level of variation in sequences in the ITS2 (internal transcribed spacers) region of ribosomal RNA was minor, and not consistent with geographical origin. These data indicate that these monogeneans invaded North America only recently, possibly in parallel with the nematode Anguillicola crassus (which is known to have been introduced with commercial imports of foreign eels). We map the current global occurrence of these monogeneans, and conclude that their dispersal from northeastern Asia was largely as a result of the eel trade, and has probably been secondarily augmented by longshore migration of infected eels, and possibly also by transport in ballast waters. With present technology, all eel stocks must still be collected from the wild; unless shipments are disinfected at quarantine, these and other eel pathogens (such as A. crassus) are likely to continue to colonise other regions of the world.
\end{abstract}

KEY WORDS: Biological invasion $\cdot$ Anguilla $\cdot$ Pseudodactylogyrus $\cdot$ Ballast $\cdot$ Monogenean $\cdot$ Pest

\section{INTRODUCTION}

Pseudodactylogyrus anguillae and $P$. bini are serious pests of anguillid eels. Heavy infestations retard production in eel-rearing facilities by causing morbidity and mortality (Buchmann 1997). P. bini is associated with hyperplasia of gill tissue, and the response is so extensive that occasionally the haptor and hindparts become embedded (Buchmann 1988). The parasites feed mainly on mucus, epithelial cells, and cells from the tissue reaction; blood from resulting haemorrhages

*Present address: Laboratory of Aquatic Animal Diseases, College of Veterinary Medicine, Chungbuk National University, Chongju, Chungbuk 361-763, Korea.

E-mail: chayward@trut.chungbuk.ac.kr may be ingested as well (Buchmann 1988). Eels produce specific antibodies against $P$. bini and $P$. anguillae, but this response is relatively weak, at least in the European species Anguilla anguilla (Buchmann 1993, Mazzanti et al. 1999).

Pseudodactylogyrus anguillae and P. bini were first recorded in Japan on the Japanese eel Anguilla japonica over 70 yr ago (Kikuchi 1929). Both worms were subsequently found to have invaded Europe in the 1980s (for example, see Gelnar et al. 1996). One of these, $P$. anguillae, was also recorded in Canada for the first time in the 1990s, on the American eel Anguilla rostrata (Cone \& Marcogliese 1995). Despite their economic importance in eel culture in both Europe and Eastern Asia, and the increasing volume of international eel shipments, their natural distribution around 
the world is largely unknown. However, the documentation of their global occurrence on the gills of all 15 species of eels is now in progress. In the present study, we report the first occurrence of 2 species of worms in the genus Pseudodactylogyrus on wild American eels A. rostrata in the United States. Morphological characters alone may not always be adequate for recognising populations that have been isolated geographically over evolutionary time. Hence, we evaluate the hypothesis that species of Pseudodactylogyrus are native to North America by comparing both their morphologies and gene sequences with congeners from other continents. An additional aim was to update the known distribution of these pests around the world by compiling all known locality records in the literature.

\section{MATERIALS AND METHODS}

Wild American eels Anguilla rostrata were electrofished from the South Fork Edisto River, and in former rice fields alongside the Cooper River, in South Carolina, USA. Eels from Chesapeake Bay, Maryland, were purchased live from commercial fishermen, who had trapped them in the Wicomico and Choptank Rivers. Details of numbers and sizes of eels, collection dates and salinities are presented in Table 1 'Results'. Eels were transported to laboratories and temporarily held until examination. Eels were anaesthetised in a solution of tricanemethanesulfonate (MS222), and the spinal chord then severed before dissection. Gills were removed, and rinsed and examined in physiological saline using a dissecting microscope. Monogenean parasites were collected and mounted on microscope slides in drops of ammonium picrate glycerine under a coverslip to draw and measure hard parts. The system for measuring hamuli and supplementary pieces follows Ogawa \& Egusa (1976). For comparison with measurements published for related worms elsewhere (see references in Table 2 'Results'), the dimensions of hard parts of 10 specimens are given as a range, in micrometers.
Nine live worms from North America were fixed individually in $100 \%$ ethanol for gene sequencing. For comparison, 5 specimens of each of Pseudodactylogyrus bini and $P$. anguillae were collected from Japanese eel Anguilla japonica, obtained from a commercial eel farm in Yoshida, Shizuoka, Japan in September 1997, and fixed in $100 \%$ ethanol. Total DNA was extracted from fixed worms using a QIAmp DNA Mini Kit (QIAGEN Inc.). Internal transcribed spacer (ITS) regions between ribosomal RNA genes were amplified using the oligonucleotide primers PD-ITS-450F (5'-AGGTGAACCTGCAGAAGGATC-3') and PD-ITS-R (5'-TAATGCTTAAATTCAGCGGGT-3'). These primers were modified from Medlin et al. (1988) and Luton et al. (1992). The PCR products were purified using a QIAquick PCR purification kit. Cycle sequencing was carried out using 1 of the above primers and 2 internal primers, PD-ITS-450F (5'-CGATGAAGAGTGCAGCAAAC-3') and PD-ITS-450R (5'-GTTTGCTGCACTCTTCATCG-3'). Sequencing products were purified by Centi-cep columns. Subsequently, products were electrophoresed by an ABI 377 DNA Sequencer (Applied Biosystems). Sequence data were edited by the Genetix Mac 9.0 sequence editor (Software Development Co.). Determination of the position of the ITS2 region was carried out by a comparison with the sequence of the ITS region of Gyrodactylus salaris as determined by Cable et al. (1999).

\section{RESULTS}

Both Pseudodactylogyrus bini and P. anguillae are reported in the United States for the first time (Table 1). This also represents the first record of $P$. bini in wild American eels.

Measurements of hard sclerites of specimens of Pseudodactylogyrus bini and P. anguillae from North America do not differ appreciably from those published for populations of these worms from Europe and Asia (Table 2), confirming the identifications. However, measurements of the supplementary piece $(\mathrm{g})$ of

Table 1. Prevalences (P) and ranges of intensities (I) of worms in the genus Pseudodactylogyrus on the gills of American eels collected in 1999 from 4 rivers in the eastern United States

\begin{tabular}{|c|c|c|c|c|c|c|c|c|}
\hline \multirow[t]{2}{*}{ River, State } & \multirow{2}{*}{$\begin{array}{c}\text { Salinity } \\
(\% \circ)\end{array}$} & \multirow{2}{*}{$\begin{array}{l}\text { Date } \\
\text { (1999) }\end{array}$} & \multirow[t]{2}{*}{$\mathrm{n}$} & \multirow{2}{*}{$\begin{array}{c}\text { Eel } \\
\text { length } \\
(\mathrm{mm})\end{array}$} & \multicolumn{2}{|c|}{ P. anguillae } & \multicolumn{2}{|c|}{ P. bini } \\
\hline & & & & & $\begin{array}{c}\mathrm{P} \\
(\%)\end{array}$ & I & $\begin{array}{l}\mathrm{P} \\
(\%)\end{array}$ & I \\
\hline Cooper, SC & 0.5 & May 19 & 1 & 250 & 100 & $>10$ & 100 & $>10$ \\
\hline & & Nov 8 & 17 & $112-464$ & 41.2 & $1->200$ & 52.9 & $1->200$ \\
\hline Sth Fork Edisto, SC & 0 & Nov 8 & 10 & $304-577$ & 80 & $1->200$ & 80 & $1->200$ \\
\hline Wicomico, MD & 15 & Nov 3 & 10 & $292-576$ & 20 & $2-3$ & 0 & 0 \\
\hline Choptank, MD & 15 & Nov 3 & 17 & $277-678$ & 17.6 & 1 & 0 & 0 \\
\hline
\end{tabular}


Table 2. Dimensions of sclerotised parts of 10 Pseudodactylogyrus anguillae and 10 P. bini collected from American eels in North America (Cooper River, South Carolina), and comparison with measurements of representatives from other localities. Hamuli measuring scheme follows Ogawa \& Egusa (1976) (see Fig. 1 for explanation of a-g)

\begin{tabular}{|c|c|c|c|c|c|c|c|c|c|c|}
\hline \multirow{2}{*}{$\begin{array}{l}\text { Continent } \\
\text { Host Anguilla: }\end{array}$} & \multirow{2}{*}{$\mathrm{a}$} & \multirow[b]{2}{*}{$\mathrm{b}$} & \multicolumn{3}{|c|}{ — Hamuli dimensions } & \multirow[b]{2}{*}{$\mathrm{f}$} & \multirow[b]{2}{*}{ g } & \multirow{2}{*}{$\begin{array}{l}\text { Dorsal } \\
\text { bar }\end{array}$} & \multirow{2}{*}{$\begin{array}{l}\text { Marginal } \\
\text { hook }\end{array}$} & \multirow[t]{2}{*}{ Source } \\
\hline & & & c & $\mathrm{d}$ & $\mathrm{e}$ & & & & & \\
\hline \multicolumn{11}{|l|}{ P. bini } \\
\hline \multicolumn{11}{|l|}{ North America } \\
\hline A. rostrata & $68-74$ & $55-60$ & $43-46$ & $7-10$ & $36-40$ & $24-25$ & $27-30$ & $42-49$ & $16-18$ & Present study \\
\hline \multicolumn{11}{|l|}{ Asia } \\
\hline A. japonica & $61-79$ & $49-61$ & $36-46$ & $7-11$ & $35-44$ & $22-30$ & - & $35-53$ & $14-18$ & Chung et al. (1984) \\
\hline A. anguilla & $67-76$ & $53-63$ & $38-43$ & $11-13$ & $33-44$ & $22-26$ & $24-26$ & $35-46$ & $15-18$ & Ogawa \& Egusa (1976) \\
\hline \multicolumn{11}{|l|}{ P. anguillae } \\
\hline \multicolumn{11}{|l|}{ North America } \\
\hline A. rostrata & $99-116$ & $88-100$ & $71-81$ & $6-10$ & $55-65$ & $31-35$ & $38-42$ & $47-58$ & $15-17$ & Present study \\
\hline \multicolumn{11}{|l|}{ Europe } \\
\hline A. anguilla & $98-118$ & $92-105$ & $54-82$ & $8-19$ & $45-78$ & $21-40$ & $30-50$ & $48-60$ & $11-18$ & Le Brun et al. (1986) \\
\hline \multicolumn{11}{|l|}{ Asia } \\
\hline A. japonica & $94-141$ & $82-114$ & $66-88$ & $5-16$ & $54-72$ & $28-34$ & - & $43-70$ & $12-18$ & Chung et al. (1984) \\
\hline A. anguilla & $101-121$ & $91-105$ & $67-84$ & $8-14$ & $54-77$ & $32-34$ & $42-48$ & $48-64$ & $14-16$ & Ogawa \& Egusa (1976) \\
\hline
\end{tabular}

P. bini from North America, at 27 to $30 \mu \mathrm{m}$, appear to be slightly longer than in specimens from Asia, at least as measured by other authors (24 to $26 \mu \mathrm{m}$, Table 2 ).

Figs. 1 to 8 depict the hard parts of both species of Pseudodactylogyrus (hamulus, dorsal bar, cirrus and accessory piece, and vaginal sclerite). Again, comparison of these illustrations with those of representatives from Europe and Asia (Ogawa \& Egusa 1980, Chung et al. 1984, Le Brun et al. 1986) reveal negligible morphological differences.

The ITS2 alignment was 462 bases long (Fig. 9). Sequences of 2 of the 4 specimens of Pseudodactylo- gyrus anguillae from the USA were identical with those of all 5 worms from Japan; the 2 remaining specimens differed from these at only a single site (\#272). The ITS2 sequences of $P$. bini from Japan showed a similar pattern, in that the 5 specimens were all identical to each other. Although no P. bini from the United States was identical to those from Japan, in several cases their sequences differed more from each other than they did from those of the Japanese $P$. bini (Fig. 9). For example, USPB3 and USPB4 differed from each other at 5 sites (\#67, 83, 158, 334 and 409), but these worms differed from the Japanese $P$. bini at just

Figs. 1 to 8. Hard parts of Pseudodactylogyrus spp. from the American eel Anguilla rostrata in North America (Cooper River, South Carolina). Scale bar $=50 \mu \mathrm{m}$

Figs. 1-4. P. bini. Fig. 1. Hamulus. a: total length, b: length without supplementary piece, c: base, $\mathrm{d}$ : external process, e: internal process, f: point, g: supplementary piece. Fig. 2. Dorsal bar. Fig. 3. Cirrus and accessory piece. Fig. 4. Vaginal sclerite

Figs. 5-8. P. anguillae. Fig. 5. Hamulus. Fig. 6. Dorsal bar. Fig. 7. Cirrus and accessory piece. Fig. 8. Vaginal sclerite
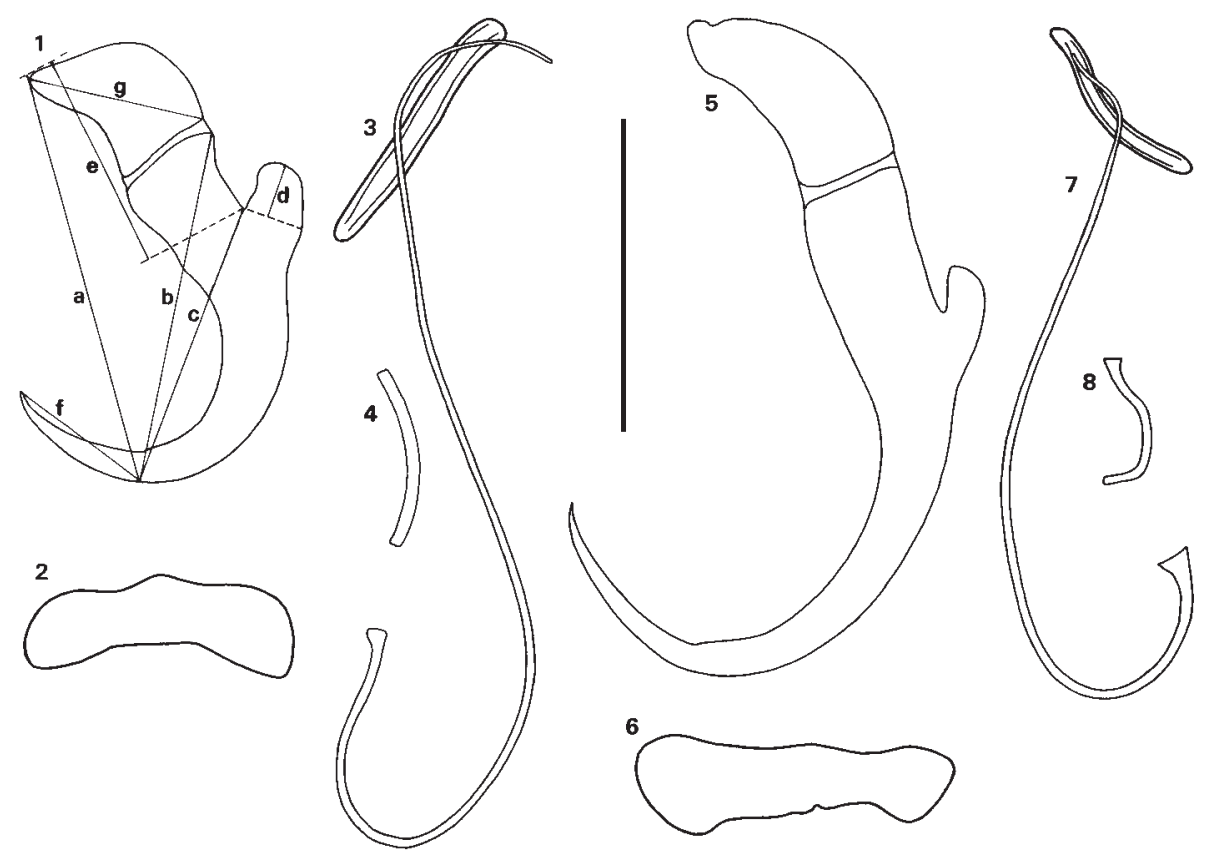


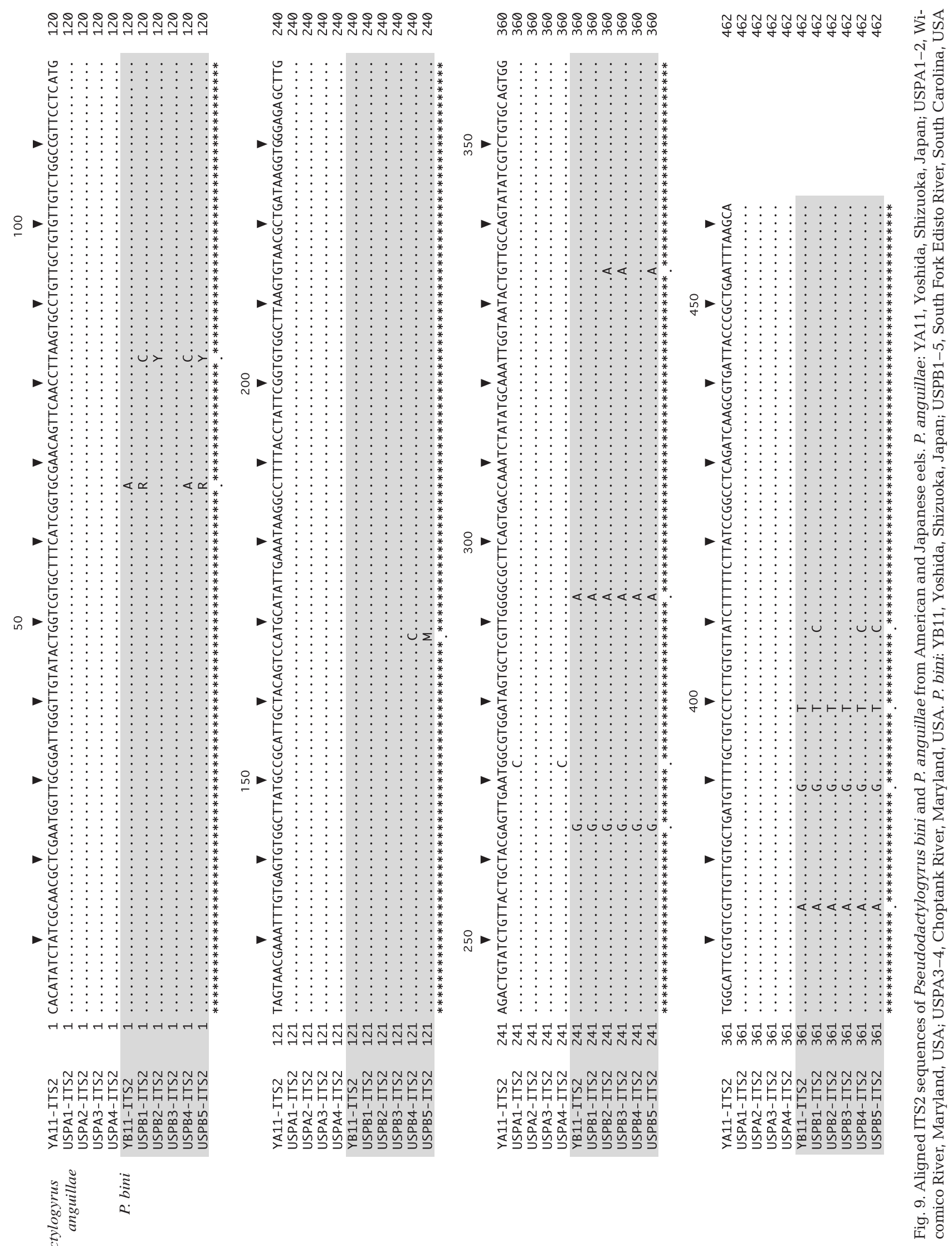


2 and 3 sites, respectively. Additionally, despite the distinct morphological differences between $P$. bini and $P$. anguillae (compare Figs. 1 to 4 with Figs. 5 to 8), their ITS2 sequences differed consistently at a total of only 5 sites (\#264, 293, 374, 389 and 399) (Fig. 9), indicating that they are closely related species.

\section{DISCUSSION}

The current known global incidences of Pseudodactylogyrus anguillae and $P$. bini are presented in Fig. 10, and now include the present records of both species for the first time in the USA. To Buchmann's distribution map (1997), we also add the other records in Europe (Saroglia et al. 1985, McCarthy \& Rita 1991, Gelnar et al. 1996, Skoríková et al. 1996, Mo \& Sterud 1998), Eastern Asia (Zhang 1981, Wang \& Wang 1990, Wu et al. 1991, Li \& Zhang 1992), and the only record of $P$. anguillae in Africa (in Egypt) (El Naggar et al. 1993) (Fig. 10). P. bini and $P$. anguillae had also been reported on $A$. reinhardtii from eastern Australia twice (Gusev 1965, Kennedy 1995). Gusev (1965) considered the material he examined from Australia to belong to 2 different 'forma', or races. However, our examinations of representative material loaned from the collection at the Russian Academy of Sciences in St. Petersburg, and Gusev's illustrations, lead us to conclude that these specimens, and probably also Kennedy's, represent 2 superficially similar but undescribed species (authors' unpubl. data), and so these records are excluded from Fig. 10.

We predict that both species of Pseudodactylogyrus probably already occur more widely in the world than documented in the present paper. Køie (1991) concluded that $P$. anguillae is more tolerant of high salinity and low temperature than $P$. bini; this was indirectly supported in the present study, as $P$. bini was absent from the cooler and more saline waters of Chesapeake Bay (Table 1). Thus, it seems likely that $P$. anguillae will be found to occur throughout most of the range of Anguilla rostrata, at least along the east coast of North America where salinities are sometimes reduced below that of sea water. Similarly, P. anguillae is likely to occur in brackish areas of northern Africa (see shaded area in Fig. 10, as modified from Tesch 1977 and Tsukamoto \& Aoyama 1998).

Morphometric data and preliminary genetic data support the conclusion that both Pseudodactylogyrus bini and $P$. anguillae are exotic to North America. If

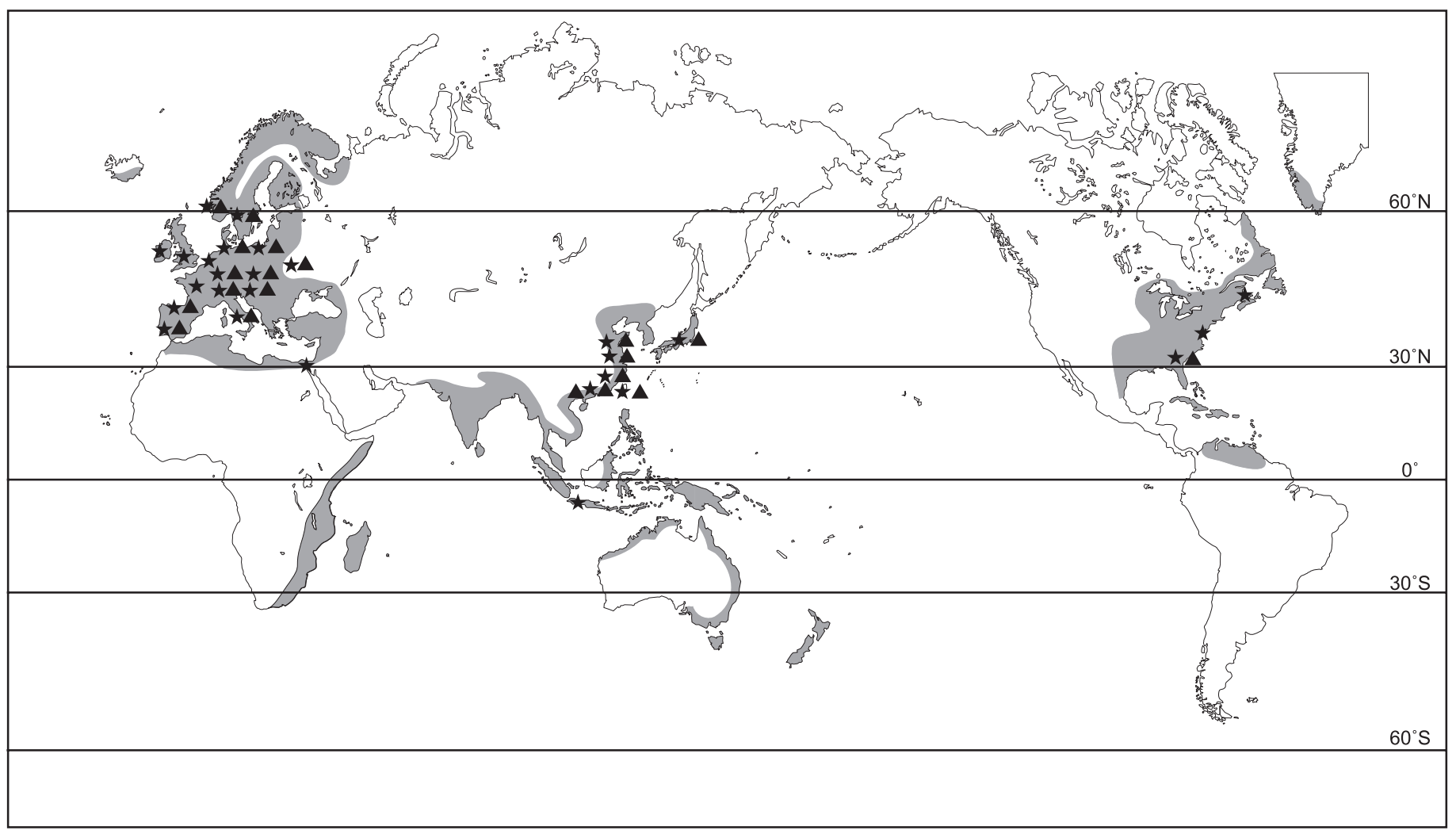

Fig. 10. Present distribution of Pseudodactylogyrus bini (₫) and P. anguillae ( $\star$ ) around the world. Shaded areas (modified from Tesch 1977 and Tsukamoto \& Aoyama 1998) indicate the freshwater occurrence of the 15 species of anguillid eels 
both species were naturally widespread from eastern North America to northeastern Asia, then we would expect their long-term isolation to have given rise to at least some detectable geographical variation. Yet, we were unable to observe such variation-either in shape and dimensions of hard parts (Figs. 1 to 8, Table 2) or in ITS2 sequences (Fig. 9). The apparent difference in length of the supplementary piece of $P$. bini is of a neglible magnitude (24 to 26 compared with 27 to 30 ), but in any case, this difference may be a mere artifact, as the worms were measured by different authors. ITS regions can be sensitive in discriminating closely related species, as variation accumulates rapidly (see Morgan \& Blair 1995, Sorensen et al. 1998). For $P$. anguillae, some individuals in the United States had ITS2 sequences identical to those in Japan, or differed by only one base (Fig. 9). On the other hand, individuals of $P$. bini from the USA differed from Japanese ones at up to only 3 sites, yet 1 pair of individuals from the Unites States differed from each other at 5 sites. This relative homogeneity is indicative of recent genetic exchange, rather than long isolation of populations on separate continents.

The occurrence of a few base-pair substitutions within the US populations of Pseudodactylogyrus bini and $P$. anguillae, but not in those from Japan (Fig. 9), is noteworthy. This finding may indicate that the North American population of both worms have multiple origins, from various localities within East Asia. To test this hypothesis, mitochondrial DNA is now being sequenced to determine within- and between-locality population structures (authors' unpubl. data). (Intraspecific variation is higher in mitochondrial DNA than in ribosomal DNA — see Blair et al. 1997.)

It is well-known that intercontinental shipments of live eels have been extensive, particularly between Europe and East Asia (for example, see Gousset 1992 and Buchmann 1997). However, we were unable to find any published reports of non-native species of eels having been imported into the USA. Nevertheless, Fries et al. (1996) strongly suspected that eel imports were responsible for the introduction of another pathogen of eels to the United States - the swimbladder nematode Anguillicola crassus. (This worm was first detected on an undisclosed eel farm in Texas, but it was not possible to check either the source of infected eels, or their specific identity.) Furthermore, anecdotal evidence from State Fisheries staff, and data freely accessible electronically on the internet, indicate that both eel producers and pet suppliers operating in the USA do import exotic species of Anguilla, particularly $A$. anguilla from Europe. Thus, we believe that the mode of spread of Pseudodactylogyrus bini and $P$. anguillae to North America was primarily, if not wholly, in shipments of live foreign eels.
In Britain, the first report of Pseudodactylogyrus anguillae was from localities distant from sites associated with the eel trade; neither was its appearance there associated with the first reports of Anguillicola crassus (Nie \& Kennedy 1991), which is well known to have invaded Europe from Eastern Asia. Furthermore, because of its small size, Nie \& Kennedy (1991) did not rule out the possibility that $P$. anguillae was an overlooked endemic parasite of European eel. Soon after, Cone \& Marcogliese (1995) detected P. anguillae for the first time in eastern North America, in Nova Scotia. As it was both rare and patchily distributed, these authors concluded that this worm was also probably native to North America (as well being native to Europe; Marcogliese \& Cone 1993). However, the historical transport of easily-identified species (such as $P$. anguillae) is often unrecognised, leading to false conclusions of natural cosmopolitanism (Carlton \& Geller 1993). Our new evidence, as well as that of the parallel local invasion of Europe and North America by another eel pathogen originating from east Asia (Anguillicola crassus) (for a recent update see Barse \& Secor 1999) and also North Africa (Elhilali et al. 1996), further supports our view that neither $P$. anguillae nor $P$. bini are native to North America, Europe or Africa.

Buchmann (1997) proposed that Pseudodactylogyrus anguillae may have reached North America in ballast water, from Europe or Asia. In support of his hypothesis was the report of the intercontinental transfer of another monogenean, Dactylogyrus amphibothrium, to the Great Lakes in ballast water, together with its host, the European ruffe Gymnocephalus cernuus (Cone et al. 1994). However, again, our finding of $P$. bini-a relatively stenohaline freshwater species (Køie 1988) in an area where freshwater ballast is not releasedtends to discredit this hypothesis as the route of introduction to North America, at least for P. bini.

On the other hand, because of its higher salinity tolerances (Køie 1988), Pseudodactylogyrus anguillae may well have invaded at least some regions as a result of ballast water transport-or simply as a result of the longshore migration of infected elvers. For example, in Egypt, i.e. in northeast Africa, so far only P. anguillae has been recorded as an invader of local eel populations; as there is no local eel trade, its incursion there is probably as a result of either the release of ballast water (or other ship water containing infected eels) from across the Mediterranean, or of the migration of infected elvers around the Mediterranean coastline. Similarly, in Norway, where the import of live eels has been banned for several years, Mo \& Sterud (1998) concluded that the recent spread of both species of Pseudodactylogyrus was, unless due to illegal import, probably due to both contamination from visiting Danish eel boats and migration of infected eels from neighbouring Sweden. 
Since we believe that the Australian material, which had been identified as Pseudodactylogyrus bini and $P$. anguillae (see Gusev 1965, Kennedy 1995), belongs to other, as yet undescribed species (because of differences in morphology and size of sclerites-compare Gusev's illustrations with our Figs. 1 to 8), this leaves only a single record of only $P$. anguillae in the southern hemisphere. Buchmann (1997) detected P. anguillae in experimentally reared Anguilla bicolor in Java, Indonesia, in 1993. This locality appears to be well outside the natural range of both $P$. bini and $P$. anguillae (Fig. 10). Once again, however, the transport of live eels - this time European eels (A. anguilla) — was involved. Young eels were imported to Bogor in Java from Germany and cultured in ponds alongside those containing A. bicolor (D. Dana, Bogor Agricultural University, pers. comm.). At the time of the importation of these eels, $P$. anguillae had already become wellestablished pests in Europe, so there is a high probability that they too were infected with one or both species of Pseudodactylogyrus.

Undoubtedly, some authors will to continue to dispute our conclusion that Pseudodactylogyrus bini and $P$. anguillae were introduced to North America, by maintaining that our results are equivocal. But the lack of geographical variation in both genes and morphological characters among populations that are supposed to have been separated for at least 25 million years cannot be more consistent with the hypothesis that both $P$. anguillae and $P$. bini were recently introduced-just as was the case for Anguillicola crassus. The hypothesis of their endemicity to North America is apparently based on the premise that because eels are an 'old' host lineage, their pseudodactylogyrids must represent an 'old' parasite lineage that has remained unchanged, both in morphology and gene sequences, in remote and relictual populations since the closing of the Tethys Sea. However, broader investigation shows that this is not a parsimonious explanation for our results. At least 1 congeneric species of Pseudodactylogyrus and at least 2 confamilial species belonging to the genus Pseudodactylogyroides infect a host group completely unrelated to eels-gobies - in the IndoWest Pacific (see Ogawa 1984, Lim 1995). Analyses of gene sequences and morphological character series (unpubl.) reveal that an ancestral species of Pseudodactylogyrus switched from gobiids to eels (and not in the opposite direction) in more recent geological time.

Reports of other monogeneans from wild Anguilla rostrata are few. Crane \& Eversole $(1980,1985)$ and Eversole (1981) recorded Gyrodactylus anguillae Ergens, 1957 on adult eels and an elver collected in the Cooper River, South Carolina, between mid-1977 and mid-1978. It is noteworthy that $G$. anguillae was first described from Europe, but is now also known from Northeast Asia
(Ogawa \& Egusa 1980). Hence, G. anguillae may have been introduced to North America in shipments of live eels as well, either directly from Europe or indirectly through Asia.

The only other report of a monogenean from wild America eels is that of Wang \& Yu (1978), who detected 'Dactylogyrus sp.' in a sample of 20 small-sized eels imported to Taiwan from Boston, in June 1978. The worms visible in Wang \& Yu's micrograph, however, strongly resemble Pseudodactylogyrus bini in morphology. Because of this, we suspect that $P$. bini and $P$. anguillae may have invaded populations of wild American eels at least 2 decades ago, but have remained undetected until now because of the relatively low level of interest in gill worms by researchers in the eastern United States.

Acknowledgements. This study was supported by a postdoctoral fellowship awarded to C.J.H. by the Japan Society for the Promotion of Science. Travel to the United States by C.J.H. and K.O. was supported by a Grant-in-Aid to Prof. Katsumi Tsukamoto (Ocean Research Institute, University of Tokyo). We thank Ms Julie Weeder (Maryland Department of Natural Resources) for permitting us to examine samples of eels from Chesapeake Bay, and for kindly hosting our visit and allowing us to use laboratory facilities at Matapeake Field Station. We thank Dr Oleg Pugachev (Russian Academy of Sciences) for facilitating our loan of Gusev's material from the Russian Academy of Sciences, and Ms Liu Hong (Shenzhen Exit-Entry Inspection and Quarantine Bureau) and Dr Nie Pin (Chinese Academy of Sciences) for kindly obtaining copies of and translating Chinese literature. We also thank anonymous reviewers for criticisms that permitted us to support our hypothesis of invasion more rigorously.

\section{LITERATURE CITED}

Barse AM, Secor DH (1999) An exotic nematode parasite of the American eel. Fisheries 24:6-10

Blair D, Agatsuma T, Watanobe T, Okamoto M, Ito A (1997) Geographical genetic structure within the human lung fluke, Paragonimus westermani, detected from DNA sequences. Parasitology 115:411-417

Buchmann, K (1988) Feeding of Pseudodactylogyrus bini (Monogenea) from Anguilla anguilla. Bull Eur Assoc Fish Pathol 8:79-81

Buchmann K (1993) A note on the humoral response of infected Anguilla anguilla against the gill monogenean Pseudodactylogyrus bini. Fish Shellfish Immunol 3:397-399

Buchmann K (1997) Infection biology of gill parasitic monogeneans with special reference to the congeners Pseudodactylogyrus bini and $P$. anguillae (Monogenea: Platyhelminthes) from European eel. Dissertation, Royal Veterinary and Agricultural University, Frederiksberg

Cable J, Harris PD, Tinsley RC, Lazarus CM (1999) Phylogenetic analysis of Gyrodactylus spp. (Platyhelminthes: Monogenea) using ribosomal DNA sequences. Can J Zool 77:1439-1449

Carlton JT, Geller JB (1993) Ecological roulette: the global transport of nonindigenous marine organisms. Science 261:78-82 
Chung HY, Lin IH, Kou GH (1984) Study of the parasites on the gill of cultured eel in Taiwan. I. Classification of dactylogyrid. COA (Counc Agric) Fish Ser 10:24-33

Cone DK, Marcogliese DJ (1995) Pseudodactylogyrus anguillae on Anguilla rostrata in Nova Scotia: an endemic or an introduction. J Fish Biol 47:177-178

Cone DK, Eurell T, Beasley V (1994) A report of Dactylogyrus amphibothrium (Monogenea) on the gills of European ruffe in western Lake Superior. J Parasitol 80:476-478

Crane JS, Eversole AG (1980) Ectoparasitic fauna of glass eel and elver stages of American eel (Anguilla rostrata). Proc World Maricult Soc 11:275-280

Crane JS, Eversole AG (1985) Metazoan ectoparasitic fauna of American eels from brackish water. Proc Annu Conf Southeast Assoc Fish Wildl Agencies 39:248-254

Elhilali MA, Yahyaoui, Sadak A, Macchi M, Taghy Z (1996) Data on anguillicolosis observed for the first time in Morocco. Bull Fr Peche Piscic 340:57-60 (in French)

El Naggar MM, Reda ES, Arafa SZ (1993) Observations on the anatomy and surface sensilla Pseudodactylogyrus anguillae (Yin and Sproston, 1948) Gusev, 1965, a monogenean gill parasite of Anguilla anguilla in Egypt. J Egypt Ger Soc Zool 11:147-175

Eversole AG (1981) Eels: parasites and aquatic chemicals. Aquacult Mag 7:40-41

Fries LT, Williams DJ, Johnson SK (1996) Occurrence of Anguillicola crassus, an exotic parasitic swim bladder nematode of eels, in the Southeastern United States. Trans Am Fish Soc 125:794-797

Gelnar M, Scholz T, Matejusova I, Konecny R (1996) Occurrence of Pseudodactylogyrus anguillae (Yin \& Sproston, 1948) and P. bini (Kikuchi, 1929), parasites of eel, Anguilla anguilla L., in Austria (Monogenea: Dactylogyridae). Ann Naturhist Mus Wien Ser B 98:1-4

Gousset B (1992) Eel culture in Japan. Bull Inst Océanogr (Monaco) (No. Spéc) 10:1-128

Gusev AV (1965) A new genus of monogenetic trematode from an eel of the genus Anguilla. Trudy Zool Inst Leningrad 35:119-125

Kennedy CR (1995) Richness and diversity of macroparasite communities in tropical eels Anguilla reinhardtii in Queensland, Australia. Parasitology 111:233-245

Kikuchi H (1929) Two new species of Japanese trematodes belonging to Gyrodactylidae. Annot Zool Jpn 12:175-186

Køie M (1988) Parasites in European eel Anguilla anguilla (L.) from Danish freshwater, brackish and marine locations. Ophelia 29:93-118

Køie M (1991) Swimbladder nematodes (Anguillicola spp.) and gill monogeneans (Pseudodactylogyrus spp.) parasitic on European eel (Anguilla anguilla). J Cons Int Explor Mer 47:391-398

Le Brun N, Lambert A, Justine JL (1986) Oncomiracidium, morphogenèse du hapteur et ultrastructure du spermatozoide de Pseudodactylogyrus anguillae (Yin et Sproston, 1948) Gusev, 1965 (Monogenea, Monopisthocotylea, Pseudodactylogyridae n. fam.). Ann Parasitol Hum Comp 61:273-284

Li GF, Zhang JY (1992) Monogenea of south China fresh water fishes XI-Monogenetic list of freshwater fishes of Guangxi. Guangxi Shifan Daxue Xuebao (J Guangxi Norm Univ) 10:90-94 (in Chinese)

Lim LHS (1995) Two new species of Pseudodactylogyroides Ogawa, 1986 (Monogenea) from two species of eleotridid fishes of Peninsular Malaysia. Syst Parasitol 31:25-32

Luton K, Walker D, Blair D (1992) Comparisons of ribosomal internal transcribed spacers from two congeneric species of flukes (Platyhelminthes: Trematoda: Digenea). Mol Biochem Parasitol 56:323-328

Marcogliese DJ, Cone DK (1993) What metazoan parasites tell us about the evolution of American and European eels. Evolution 47:1632-1635

Mazzanti C, Monni G, Cognetti Varriale AM (1999) Observations on antigenic activity of Pseudodactylogyrus anguillae (Monogenea) on the European eel (Anguilla anguilla). Bull Eur Assoc Fish Pathol 19:57-59

McCarthy TK, Rita SD (1991) The occurrence of the monogenean Pseudodactylogyrus anguillae (Yin and Sproston) on migrating silver eels in western Ireland. Ir Nat $\mathrm{J} 23$ : 473-477

Medlin L, Elwood HJ, Stickel S, Sogin ML (1988) The characterization of enzymatically amplified eukaryotic 16S-like rRNA-coding regions. Gene 71:491-499

Mo TA, Sterud E (1998) First observations of Pseudodactylogyrus spp. and other parasites in wild eel (Anguilla anguilla L.) in Norway. Bull Scand Soc Parasitol 8:1-5

Morgan JAT, Blair D (1995) Nuclear rDNA ITS sequence variation in the trematode genus Echinostoma: an aid to establishing relationships within the 37-collar-spine group. Parasitology 111:609-615

Nie P, Kennedy CR (1991) Occurrence and seasonal dynamics of Pseudodactylogyrus anguillae (Yin \& Sproston) (Monogenea) in eel, Anguilla anguilla (L.), in England. J Fish Biol 39:897-900

Ogawa K (1984) Pseudodactylogyrus haze sp. nov., a gill monogenean from the Japanese goby, Acanthogobius flavimanus. Jpn J Parasitol 33:403-405

Ogawa K, Egusa S (1976) Studies on eel pseudodactylogyrosis-I. Morphology and classification of three eel dactylogyrids with a proposal of a new species, Pseudodactylogyrus microrchis. Bull Jpn Soc Sci Fish 42:395-404

Ogawa K, Egusa S (1980) Gyrodactylus infestations of cultured eels (Anguilla japonica and A. anguilla) in Japan. Fish Pathol 15:95-99

Saroglia MG, Fantin P, Arlati G (1985) Eel production in Italy - problems and perspectives. EIFAC (FAO) Working Party on Eel, Perpignan, France, 17-18 September 1985

Skoríková B, Scholz T, Moravec F (1996) Spreading of introduced monogeneans Pseudodactylogyrus anguillae and $P$. bini among eel populations in the Czech Republic. Folia Parasitol 43:155-156

Sorensen RE, Curtis J, Minchella DJ (1998) Intraspecific variation in the rDNA ITS loci of 37-collar-spined echinostomes from North America: implications for sequence-based diagnoses and phylogenetics. J Parasitol 84:992-997

Tesch FW (1977) The eel. Chapman and Hall, London

Tsukamoto K, Aoyama J (1998) Evolution of freshwater eels of the genus Anguilla: a probable scenario. Environ Biol Fish 52:139-148

Wang FQ, Wang YA (1990) Parasites of Anguilla japonica Temminck et Schlegel. Sichuan J Zool 9:30-31 (in Chinese)

Wang YL, Yu TC (1978) A preliminary report on parasitic diseases of South Africa's glass eels (Anguilla mossambica) and northeastern America's glass eel (Anguilla rostrata). COA (Counc Agric) Fish Ser 11:52-55 (in Chinese)

Wu BH, Sun XD, Song CC (1991) Fauna of Zhejiang. Trematoda. Zhejiang Science and Technology Publishing House, Zhejiang (in Chinese)

Zhang JY (1981) Thirty-five species of monogenetic trematodes from freshwater fishes in China. J Sth China Norm Coll (Univ), Nat Sci Ed 1981:62-76 (in Chinese)

Submitted: August 2, 2000; Accepted: October 6, 2000

Proofs received from author(s): December 20, 2000 